\title{
Literature Review: Risk Factors for Lung Physiological Disorders Due to Exposure to Wood Dust
}

\section{Literatur Review: Faktor Risiko Gangguan Faal Paru Akibat Paparan Debu Kayu}

\author{
Prayudha Ardyaswarai \\ Departement of Biostatistics and Population, Faculty of Public Health Universitas Airlangga \\ Campus C Mulyorejo, Surabaya, East Java 60115 Indonesia
}

\begin{abstract}
Introduction: The wood processing industry in Indonesia is experiencing very rapid development, so there are positive and negative impacts of this industry for the country. The positive impacts that occur such as increased economic growth while the negative impacts that occur include environmental pollution which directly impacts the health of workers. One of the bad effects experienced by workers working in the industrial sector is wood dust. Wood dust is an invisible object that can circulate through the air so that it can enter the body and cause disruption of lung function of workers. The purpose of this research to conduct research on the factors of lung physiology disorders caused by vulnerability to wood dust. Method: The method was used in this research is a literature review by reviewing 10 relevant articles. Results: The effects showed that the method used is the same, which is using cross sectional, and during the study the data collection tools used questionnaires with interviews. In line with the outcomes of the study, factors for pulmonary physiology are not only caused by dust levels that exceeded the threshold value (NAV), but there are several other factors, namely individual characteristics such as length of service, duration of exposure, smoking habits, and use of personal protective equipment (PPE). Moreover, several studies presented bivariate tests to find out the relationship between variables that are factors in the occurrence of pulmonary physiology. Conclusions: Variables that significantly influence the occurrence of pulmonary physiology are the use of personal protective equipment (PPE) and wood dust levels that exceed the threshold value (NAV).
\end{abstract}

Keywords: literature review, pulmonary physiology, risk factor, wood dust

\section{ABSTRAK}

Pendahuluan: Industri pengolahan kayu di Indonesia mengalami pertumbuhan yang sangat pesat, sehingga terdapat dampak positif dan negative bagi negara. Dampak positif yang terjadi seperti pertumbuhan ekonomi yang meningkat sedangkan dampak buruk pencemaran lingkungan hingga berpengaruh langsung terhadap kesehatan pekerja. Salah satu dampak buruk tersebut ialah debu kayu. Debu kayu merupakan benda yang tidak terlihat yang dapat menyebar melalui udara sehingga dapat masuk kedalam tubuh menyebabkan terjadinya gangguan faal paru pada pekerja. Metode:Yang digunakan pada penelitian ini adalah literatur review dengan mereview 10 jurnal yang relevan. Hasil: Metode penelitian yang dipergunakan oleh hasil penelitian yang menjadi bahan literature review memiliki desain yang sama yaitu memakai cross sectional dan selama penelitian alat pengumpulan data menggunakan kuisioner dan wawancara. Sejalan dengan hasil penelitian tersebut faktor terjadinya gangguan faal paru tidak hanya dari kadar debu yang melebihi nilai ambang batas (NAB) namun terdapat beberapa faktor lain yaitu karakteristik individu seperti masa kerja, lama paparan, kebiasaan merokok, dan penggunaan alat pelindung diri (APD). Sehingga dari beberapa penelitian mensajikan uji bivariat untuk mengetahui hubungan antar variabel yang menjadi faktor terjadinya gangguan faal paru. Simpulan: Beberapa penelitian menunjukkan bahwa faktor yang secara signifikan mempengaruhi terjadinya gangguan faal paru adalah penggunaan alat pelindung diri (APD) dan kadar debu kayu yang melebih nilai ambang batas (NAB).

Kata kunci: debu kayu, faktor risiko, gangguan faal paru, literatur review

Corresponding Author:

Prayudha Ardyaswara

Email: prayudha.ardyaswara-2016@fkm.unair.ac.id

Telephone: +6282257690100

\section{INTRODUCTION}

The growth of an increasingly advanced industry provides benefits for each country. The profits are derived from the industrial sector, which annually provides new jobs for actors. However, apart from these advantages, there are potential hazards in the work environment that have an impingement 
on the health of workers. Physical environmental factors that are often found in the work environment pose a great threat to health problems for workers. Physical environmental factors such as debris, noise, temperature and work climate which have a direct effect on workers can cause occupational accidents and diseases (Purba, Adiputra and Muliarta, 2019). individual factors include non-obedience of using respiratory protectors, smoking habits, length of work, and working (Anselma, Trisnawati and Saleh, 2019).

Occupational diseases are found in the work environment and are frequently exposed in workers. One of the causes of occupational diseases is dust. Debris is an invisible object of various sizes that can spread through the air and enter the body through the eyes, nose and skin pores (Putri, Suwondo and Widjasena, 2016). Dust has various types, namely organic and inorganic debris. One of the organic dust that can cause health problems wood dust. In various studies, it is mentioned that a long exposure to dust can cause danger, particularly in the lung organs of the workers. Workers who often experience health problems, particularly wood dust are workers who work in the wood processing industry.

The wood processing industry has a very rapid development in Indonesia (Ida, Doke and Salmun, 2019). Indonesia is also the country that owns the largest tropical forest after Brazil, thereby supporting the growth of the wood processing industry. At present the industry in Indonesia brings positive and negative impacts. The positive impacts that occur is the economic growth, while the negative is environmental pollution which brings detrimental impacts on organs such as skin disorders, digestive tract disorders, abnormalities in the optics, and disorders of the respiratory tract (Alfabet, Suhartono and Nugroho, 2017).

The wood processing industry has various components that can trigger the appearance of pulmonary physiology disorders in the wood processing workforce. This is caused by dust, which includes particle size, physique, concentration, and duration of exposure (Purba, Adiputra and Muliarta, 2019). Small wood dust particles that are not visible to the eye can affect the air quality around the wood processing industry. Air quality mixed with wood dust will later affect the health conditions of the lungs of workers.

Lung health of actors can be known through medical examinations using spirometry. Medical examination of the lungs produces output in the course of normal lung conditions, obstruction, and restrictions. Lung examination can also be managed non-medically by knowing other complaints on breathing that are characterized by symptoms such as coughing, shortness of breath, asthma, and other symptoms related to breathing (Rohmah, Thohari and Sunarko, 2017).

The high number of workers affected by lung health disorders has encouraged researchers to conduct research on the factors of lung physiology disorders caused by vulnerability to wood dust.

\section{METHODS}

The journals used in the literature review were obtained from an electronic journal provider database, namely through Google Scholar, Research gate, and DOAJ with keywords, namely lung function disorder, wood dust levels, and wood processing industry (google scholar), "lung function", " wood dust "(research gate and DOAJ). The selection of journals was done by screening journals published in the last 5 years. After the screening process, the next step was to sort out the journals according to the inclusion criteria, namely primary research with cross sectional design, not descriptive research.

The search results obtained as many as 81 journals on Google scholar, 10 journals on DOAJ, and one journal on Research Gate. Afterwards, the total journals obtained were 92 journals. Of the 92 journals a screening was conducted, and a total of 42 journals were obtained. Journals that met the screening were then passed through the selection according to inclusion criteria until as many as 12 journals were obtained. The final stage in the selection of journals was to determine the independent and dependent variables that had been determined by the researcher and finally 10 relevant journals and "full text" were obtained.

\section{RESULTS}

\section{The problems brought up in the study}

Based on the problems related to lung function disorders, many studies have been carried out on wood dust, which is a risk factor for occupational diseases. The basic problem raised in the study of Permatasari, Raharjo and Joko (2017) and Alfabet, Suhartono and Nugroho (2017) lies in the work area of a wood processing company that showed dusty 


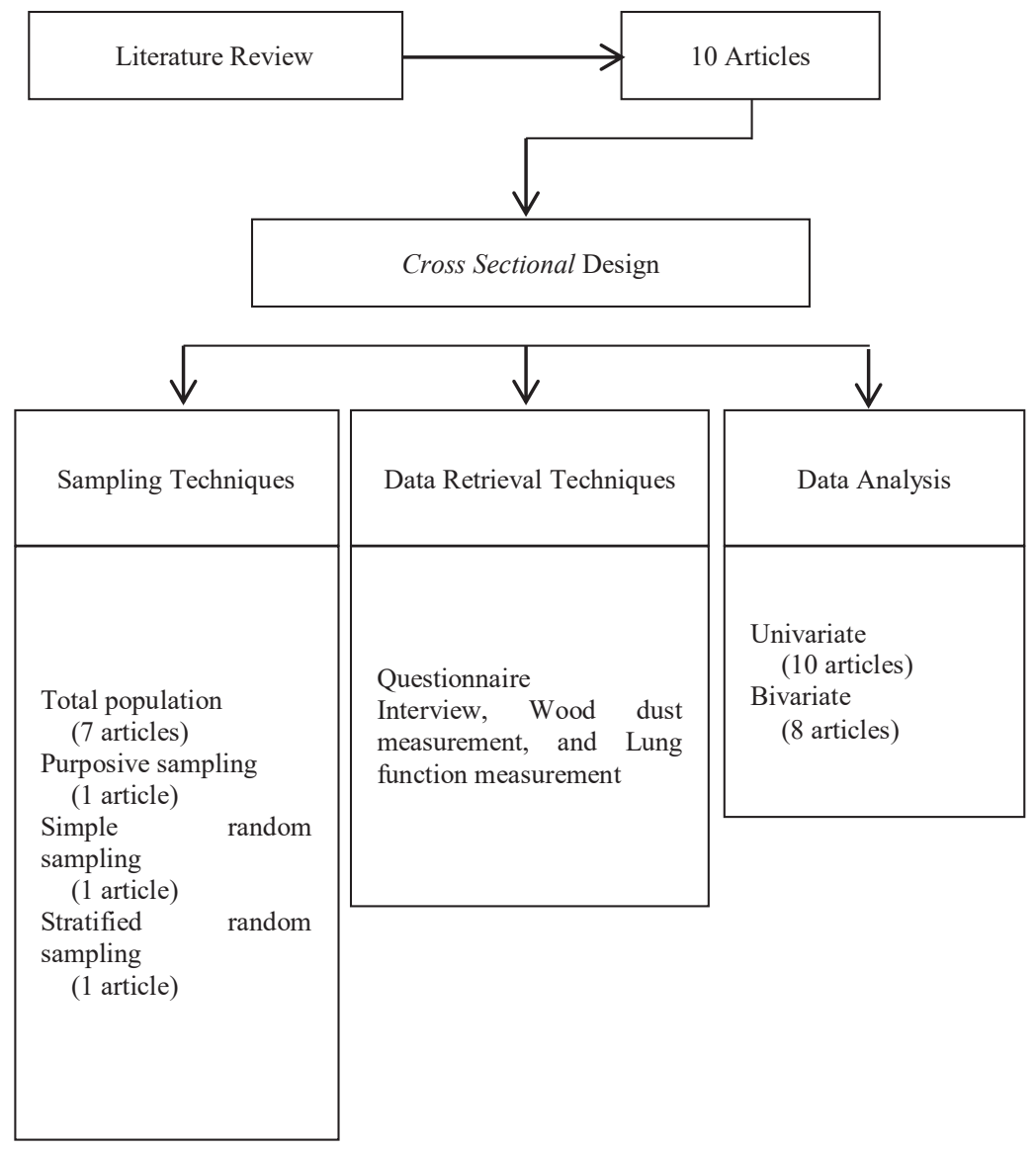

Figure 1. Articles Research Step

conditions with a number of workers complaining of respiratory problems. Respiratory problems experienced by workers occured because of the behavior of workers who were less obedient in the role of personal protective equipment (PPE). The results are in line with research by Maratus MS, Suroto and Ekawati (2018) which investigated the dusty working environment in the furniture industry. It was found that workers did not receive health check facilities and workers had a lack of understanding about wearing masks correctly. It could be observed from the fact that workers often did not change masks during work.

In research of Putri, Darundiati and Dewanti (2017) and Nafisa, Joko and Setiani (2016) there was a problem of floating dust that occurred in the room air and accumulated, so it was inhaled by workers and increased the danger of lung function disorders. Meanwhile, in the journal of Anjani, Raharjo and Budiyono (2018) based on the results of interviews with 10 workers in the sanding section there were 7 people experiencing interference with the presence of dust at work, 2 workers experiencing health problems, and one person did not experience complaints of health problems. In the article of Sumekar and Ediningsih (2016) the results showed that the large amount of wood dust could cause pulmonary physiology, and in the study of Isnaini, Setyoko and Basuki (2015) it was found that there was a problem experienced by y workers who had worked over 5 years. According to research by Oviera, Jayanti and Suroto (2016) there were various problems that occurred in the workplace, such as the number of workers who experienced complaints of lung physiology, and in research by Fujianti, Hasyim and Sunarsih (2015) it was stated that workers experienced symptoms of lung health disorders. Thus, based on the literature review results from 10 journals related to the background of the research problem, it is known that the cause of the existence of pulmonary physiology disorders in workers comes from the exposure to wood dust mixed with air in the work environment, and the worker's behavior that can trigger health problems due to lack of knowledge related to health checks and attitudes of not caring about the use of personal protective equipment (PPE) at work. 
Table 1. Literature Review Tabel

\begin{tabular}{|c|c|c|c|c|c|}
\hline Researcher & Title & $\begin{array}{c}\text { R e s e a r c h } \\
\text { Design }\end{array}$ & Respondents & Research Step & Results \\
\hline $\begin{array}{l}\text { Nafisa, Joko } \\
\text { and Setiani } \\
(2016)\end{array}$ & $\begin{array}{l}\text { Relationship } \\
\text { between } \\
\text { Exposure } \\
\text { to Wood } \\
\text { Dust at Work } \\
\text { Environment } \\
\text { andImpaired } \\
\text { Function of } \\
\text { Lungs on } \\
\text { Workers at } \\
\text { PT. Arumbai } \\
\text { Kasembadan, } \\
\text { Banyumas }\end{array}$ & Cross sectional & $\begin{array}{l}\text { All personnel } \\
\text { working in the } \\
\text { production unit } \\
\text { of PT. Arumbai } \\
\text { Kasembadan, } \\
\text { Banyumas. } \\
\text { A total of } \\
128 \text { people } \\
\text { consisting of } \\
54 \text { men and } 74 \\
\text { women }\end{array}$ & $\begin{array}{l}\text { The primary data } \\
\text { were obtained through } \\
\text { interviews with the } \\
\text { use of questionnaires. } \\
\text { Moreover, the } \\
\text { measurements of } \\
\text { the levels of dust in } \\
\text { total were performed } \\
\text { using Haz Dust } \\
\text { EPAM- 5000, while } \\
\text { the measurements of } \\
\text { the function of the } \\
\text { lungs of workers were } \\
\text { performed by using a } \\
\text { spirometer. }\end{array}$ & $\begin{array}{l}\text { Pulmonary function disorders } \\
\text { in workers in the production } \\
\text { unit of PT. Arumbai } \\
\text { Kasembadan Banyumas } \\
\text { based on the results of the } \\
\text { study were influenced by the } \\
\text { levels of dust in the work } \\
\text { environment that exceeded } \\
\text { the value of threshold limit } \\
\text { (NAB), a period of work } \\
\text { which was too long, so the } \\
\text { workers were often exposed } \\
\text { too much to the dust timber, } \\
\text { and the behavior of workers } \\
\text { in the use of PPE (masks) } \\
\text { which was less obedient. On } \\
\text { individual characteristics } \\
\text { only univariate analysis was } \\
\text { performed. }\end{array}$ \\
\hline $\begin{array}{l}\text { Permatasari, } \\
\text { Raharjo and } \\
\text { Joko (2017) }\end{array}$ & $\begin{array}{l}\text { Relationship } \\
\text { between Total } \\
\text { Dust Levels } \\
\text { and Personal } \\
\text { Hygiene with } \\
\text { Lung Function } \\
\text { Disorders } \\
\text { in Wood } \\
\text { Processing } \\
\text { Workers at CV } \\
\text { Indo Jati Utama } \\
\text { Semarang }\end{array}$ & Cross sectional & $\begin{array}{l}\text { Sampling was } \\
\text { conducted } \\
\text { using the } t \\
\text { stratified random } \\
\text { sampling } \\
\text { technique } \\
\text { which classified } \\
\text { respondents into } \\
\text { small groups } \\
\text { called strata. } \\
\text { There were as } \\
\text { many as } 38 \\
\text { workers as the } \\
\text { total samples } \\
\text { in the wood } \\
\text { processing unit } \\
\text { in this study }\end{array}$ & $\begin{array}{l}\text { The collection } \\
\text { of data was done } \\
\text { using interview } \\
\text { questionnaires. } \\
\text { Moreover, the } \\
\text { secondary data were } \\
\text { obtained for the } \\
\text { results of total dust } \\
\text { levels inhaled, so } \\
\text { the researchers only } \\
\text { categorized workers } \\
\text { who were in the work } \\
\text { environment with } \\
\text { dust content levels } \\
\text { above the NAV and } \\
\text { below the NAV. } \\
\text { The measurements } \\
\text { of health lungs } \\
\text { of workers were } \\
\text { conducted using } \\
\text { spirometer. }\end{array}$ & $\begin{array}{l}\text { Based on the results of the } \\
\text { research conducted at CV } \\
\text { Indo Jati Utama Semarang } \\
\text { related to impaired lung } \\
\text { function in timber processing } \\
\text { workers, it is known that } \\
\text { the total concentration of } \\
\text { dust, the levels of dust } \\
\text { inhalation and the use of PPE } \\
\text { had a relationship with the } \\
\text { occurrence of lung function } \\
\text { disorders of workers because } \\
\text { the workers dis not always use } \\
\text { PPE. Meanwhile, the length } \\
\text { of work, years of service, and } \\
\text { nutritional status were not } \\
\text { related to the occurrence of } \\
\text { lung function disorders. }\end{array}$ \\
\hline $\begin{array}{l}\text { Putri, } \\
\text { Darundiati and } \\
\text { Dewanti (2017) }\end{array}$ & $\begin{array}{l}\text { Relationship } \\
\text { of Wood Dust } \\
\text { Inhalation } \\
\text { Exposure to } \\
\text { Lung Function } \\
\text { Disorders in } \\
\text { Workers in } \\
\text { the Furniture } \\
\text { Industry CV. } \\
\text { Citra Jepara } \\
\text { Furniture } \\
\text { Semarang } \\
\text { Regency }\end{array}$ & Cross sectional & $\begin{array}{l}\text { This study used } \\
\text { all the total } \\
\text { population or } \\
\text { all workers in } \\
\text { CV Citra Jepara, } \\
\text { Semarang } \\
\text { Regency. This } \\
\text { study also met } \\
\text { the inclusion } \\
\text { criteria of } 30 \\
\text { people. }\end{array}$ & $\begin{array}{l}\text { The measurement of } \\
\text { levels of dust inhaled } \\
\text { was conducted using } \\
\text { a Personal Dust } \\
\text { Sampler for } 1 \text { hour } \\
\text { of work. Meanwhile, } \\
\text { room dust levels were } \\
\text { measured using High } \\
\text { Volume Air Sampler } \\
\text { (HVAS) with the } \\
\text { gravimetric method. } \\
\text { The measurement of } \\
\text { lung function was } \\
\text { done using spirometer. } \\
\text { Besides, the collection } \\
\text { of data were done } \\
\text { using interview } \\
\text { questionnaires. }\end{array}$ & $\begin{array}{l}\text { In this study, the univariate } \\
\text { analysis showed the } \\
\text { characteristics of workers } \\
\text { and the bivariate analysis } \\
\text { only discussed relevant } \\
\text { levels of dust inhalation. } \\
\text { Thus, the relationship of two } \\
\text { independent variables free and } \\
\text { dependent variables was only } \\
\text { for the levels of dust and } \\
\text { lung function disorders. For } \\
\text { other variables that were not } \\
\text { directly affect the condition of } \\
\text { the lungs were not described } \\
\text { in the bivariate analysis. It } \\
\text { was found that the dust levels } \\
\text { and the occurrence of lung } \\
\text { function disorders in this study } \\
\text { had a relationship. }\end{array}$ \\
\hline
\end{tabular}


Continued Table 1.

\begin{tabular}{|c|c|c|c|c|c|}
\hline Researcher & Title & $\begin{array}{c}\text { R e s e a r c h } \\
\text { Design }\end{array}$ & Respondents & Research Step & Results \\
\hline $\begin{array}{l}\text { Maratus MS, } \\
\text { Suroto and } \\
\text { Ekawati (2018) }\end{array}$ & $\begin{array}{l}\text { The Relationship } \\
\text { between } \\
\text { Exposure to } \\
\text { Wood Dust and } \\
\text { the Lung Vital } \\
\text { Capacity of } \\
\text { Wood Cutting } \\
\text { Workers in PT. } \\
\text { X Mranggen, } \\
\text { Central Java }\end{array}$ & Cross sectional & $\begin{array}{l}\text { This study used } \\
\text { total sampling or } \\
\text { total population } \\
\text { to determine the } \\
\text { respondents. } \\
\text { As many as } 30 \\
\text { workers in the } \\
\text { section of cutting } \\
\text { wood were } \\
\text { selected as the } \\
\text { respondents. }\end{array}$ & $\begin{array}{l}\text { The research } \\
\text { was carried out } \\
\text { using interview } \\
\text { questionnaires. several } \\
\text { measurements were } \\
\text { performed on index } \\
\text { mass body (BMI), } \\
\text { the the capacity of } \\
\text { vital lung using a } \\
\text { spirometer, the levels } \\
\text { of total dust of timber } \\
\text { using High Volume } \\
\text { Air Sampler (HVAS), } \\
\text { temperature and } \\
\text { humidity. }\end{array}$ & $\begin{array}{l}\text { The results of the research } \\
\text { presented in the analysis } \\
\text { of bivariate were about } \\
\text { the concentration of dust } \\
\text { in total with a vital lung } \\
\text { capacity. The two variables } \\
\text { were known to have a } \\
\text { significant relationship. The } \\
\text { shortcomings in this journal } \\
\text { is that there was no bivariate } \\
\text { on other variables like work } \\
\text { period, the use of PPE, the } \\
\text { habit of smoking, the habit } \\
\text { of exercise, a health history } \\
\text { of the workers, the levels of } \\
\text { dust timber, and the vital } \\
\text { lung. Thus, in this study } \\
\text { other variables were not } \\
\text { known to be associated with } \\
\text { the causes of lung function } \\
\text { disorders in workers. }\end{array}$ \\
\hline $\begin{array}{l}\text { Anjani, Raharjo } \\
\text { and Budiyono } \\
(2018)\end{array}$ & $\begin{array}{l}\text { Relationship } \\
\text { between the } \\
\text { Levels of Dust } \\
\text { Inhalation } \\
\text { with Impaired } \\
\text { Function of } \\
\text { Lungs on } \\
\text { Workers in } \\
\text { the Furniture } \\
\text { Industry at PT } \\
\text { Marleny Jepara }\end{array}$ & Cross sectional & $\begin{array}{l}\text { Sampling used } \\
\text { simple random } \\
\text { sampling } \\
\text { technique. The } \\
\text { sampling selection } \\
\text { was also in } \\
\text { accordance with } \\
\text { the criteria for } \\
\text { inclusion. Out of } \\
42 \text { total population } \\
\text { in this study, there } \\
\text { were } 30 \text { samples of } \\
\text { furniture industry } \\
\text { workers who } \\
\text { participated in the } \\
\text { study. }\end{array}$ & $\begin{array}{l}\text { The research } \\
\text { was conducted } \\
\text { using interview } \\
\text { questionnaires. The } \\
\text { measurement of the } \\
\text { levels of dust inhaled } \\
\text { was performed } \\
\text { using Personal Dust } \\
\text { Sampler during the } \\
\text { first hour of work, } \\
\text { the sampling of the } \\
\text { air was done using } \\
\text { the MVAS tool, the } \\
\text { measurement of the } \\
\text { function of the lungs } \\
\text { was done using a } \\
\text { spirometer. }\end{array}$ & $\begin{array}{l}\text { Results of the study } \\
\text { performed by bivariate } \\
\text { analysis showed that } \\
\text { levels of dust inhalation } \\
\text { were associated with } \\
\text { impaired lung function. } \\
\text { Other variables were only } \\
\text { presented in univariate } \\
\text { analysis. Thus, little was } \\
\text { known about the relationship } \\
\text { of other variables that could } \\
\text { influence the occurrence } \\
\text { of impaired lung function } \\
\text { on workers in the furniture } \\
\text { industry of PT Marleny } \\
\text { Jepara. }\end{array}$ \\
\hline $\begin{array}{l}\text { Alfabet, } \\
\text { Suhartono and } \\
\text { Nugroho (2017) }\end{array}$ & $\begin{array}{l}\text { Relationship } \\
\text { between several } \\
\text { factors with } \\
\text { Lung Function } \\
\text { on Employed } \\
\text { Women in } \\
\text { the Furniture } \\
\text { Industry } \\
\text { Furniture at PT. } \\
\text { Ebako Nusantara } \\
\text { Semarang } \\
\text { Trimester II } \\
\text { Year } 2017\end{array}$ & Cross sectional & $\begin{array}{l}\text { Determination of } \\
\text { the respondents } \\
\text { in this study was } \\
\text { performed using } \\
\text { the technique } \\
\text { of purposive } \\
\text { sampling in } \\
\text { accordance with } \\
\text { the specified } \\
\text { criteria. The total } \\
\text { of } 37 \text { workers } \\
\text { were selected as } \\
\text { respondents in } \\
\text { this study, divided } \\
\text { into } 22 \text { workers in } \\
\text { the Final Sanding } \\
\text { Department and } \\
15 \text { workers in } \\
\text { the Finishing } \\
\text { Department. }\end{array}$ & $\begin{array}{l}\text { The measurement } \\
\text { of respondents' } \\
\text { lung function } \\
\text { was performed } \\
\text { using a spirometer } \\
\text { and interview } \\
\text { questionnaires. }\end{array}$ & $\begin{array}{l}\text { Variables studies using } \\
\text { bivariate analysis were a } \\
\text { period of work, the use } \\
\text { of PPE, and the status of } \\
\text { nutrition. It was found } \\
\text { that the use of PPE was } \\
\text { associated with factors } \\
\text { that caused lung function } \\
\text { disorders. Meanwhile, } \\
\text { the two variables, period } \\
\text { of work and the status } \\
\text { of nutrition, were not } \\
\text { associated with the factors } \\
\text { causing the occurrence of } \\
\text { lung function disorders. } \\
\text { Meanwhile, the univariate } \\
\text { analysis only studied lung } \\
\text { function. }\end{array}$ \\
\hline
\end{tabular}


Continued Table 1.

\begin{tabular}{|c|c|c|c|c|c|}
\hline Researcher & Title & $\begin{array}{c}\text { R e s e a r c h } \\
\text { Design }\end{array}$ & Respondents & Research Step & Results \\
\hline $\begin{array}{l}\text { Fujianti, } \\
\text { Hasyim and } \\
\text { Sunarsih (2015) }\end{array}$ & $\begin{array}{l}\text { Factors That } \\
\text { Influence the } \\
\text { Occurrence of } \\
\text { Respiratory } \\
\text { Disorders in } \\
\text { Blessed Teak } \\
\text { Furniture } \\
\text { Workers, Jambi } \\
\text { City in } 2012\end{array}$ & Cross sectional & $\begin{array}{l}\text { Determination of } \\
\text { respondents in this } \\
\text { study used total } \\
\text { sampling or a total } \\
\text { population of } 33 \\
\text { people }\end{array}$ & $\begin{array}{l}\text { The data collection } \\
\text { in this research was } \\
\text { obtained by interview } \\
\text { questionnaires, } \\
\text { measuring the air of } \\
\text { work environment } \\
\text { using the Haz Dust } \\
\text { EPAM } 5000 \text { air } \\
\text { sampler, and the } \\
\text { masurement of the } \\
\text { temperature was done } \\
\text { using a hygrometer. }\end{array}$ & $\begin{array}{l}\text { This study already used } \\
\text { univariate analysis and } \\
\text { bivariate analysis on all } \\
\text { variables. Thus, it was } \\
\text { found that the load of work, } \\
\text { duration of exposure, age, } \\
\text { wood dust content, and the } \\
\text { use of PPE affected the } \\
\text { occurrence of pulmonary } \\
\text { disorders. }\end{array}$ \\
\hline $\begin{array}{l}\text { Suroto, Jayanti } \\
\text { and Oviera } \\
(2016)\end{array}$ & $\begin{array}{l}\text { Factors } \\
\text { Associated } \\
\text { with Lung's } \\
\text { Vital Capacity } \\
\text { in Wood } \\
\text { Processing } \\
\text { Industry } \\
\text { Workers at PT. } \\
\text { X Jepara }\end{array}$ & Cross sectional & $\begin{array}{l}\text { Determination of } \\
\text { respondents in } \\
\text { this study used } \\
\text { a total sampling } \\
\text { method or a total } \\
\text { population of } 37 \\
\text { people. }\end{array}$ & $\begin{array}{l}\text { Data collection } \\
\text { in this study used } \\
\text { a spirometer to } \\
\text { measure lung capacity } \\
\text { and interview } \\
\text { questionnaires. }\end{array}$ & $\begin{array}{l}\text { This study already used } \\
\text { univariate analysis and } \\
\text { bivariate analysis, but the } \\
\text { results of the bivariate } \\
\text { analysis were not presented } \\
\text { in the table. Based on the } \\
\text { results of the bivariate } \\
\text { analysis, gender and } \\
\text { smoking habits affected the } \\
\text { occurrence of pulmonary } \\
\text { disorders }\end{array}$ \\
\hline $\begin{array}{l}\text { Sumekar and } \\
\text { Ediningsih } \\
(2016)\end{array}$ & $\begin{array}{l}\text { Factors Related } \\
\text { to the Lung } \\
\text { Function Status } \\
\text { of Workers } \\
\text { Exposed to Dust } \\
\text { in the Furniture } \\
\text { Industry at CV. } \\
\text { Annet Sofa } \\
\text { Pandowoharjo } \\
\text { Sleman } \\
\text { Yogyakarta }\end{array}$ & Cross sectional & $\begin{array}{l}\text { Determination } \\
\text { of the sample of } \\
\text { respondents in } \\
\text { this study used } \\
\text { total sampling, } \\
\text { where there was a } \\
\text { similar number of } \\
\text { sampling as the } \\
\text { population. }\end{array}$ & $\begin{array}{l}\text { Data collection in } \\
\text { this study was done } \\
\text { using interview } \\
\text { questionnaires. }\end{array}$ & $\begin{array}{l}\text { This study the used } \\
\text { unvariate and bivariate } \\
\text { analysis, and the results } \\
\text { showed that the use } \\
\text { of personal protective } \\
\text { equipment (PPE), smoking } \\
\text { habits, and length of service } \\
\text { were associated with the } \\
\text { occurrence of pulmonary } \\
\text { disorders. }\end{array}$ \\
\hline $\begin{array}{l}\text { Isnaini, Setyoko } \\
\text { and Basuki } \\
(2015)\end{array}$ & $\begin{array}{l}\text { Relationship } \\
\text { between Dust } \\
\text { Exposure } \\
\text { and Smoking } \\
\text { Habits with } \\
\text { Lung Function } \\
\text { in Antique } \\
\text { Furniture } \\
\text { Workers in } \\
\text { Jepara }\end{array}$ & $\begin{array}{l}\text { Cross } \\
\text { Sectional }\end{array}$ & $\begin{array}{l}\text { Determination } \\
\text { of the sample of } \\
\text { respondents in this } \\
\text { study used a total } \\
\text { sampling of } 46 \\
\text { people. }\end{array}$ & $\begin{array}{l}\text { This data collection } \\
\text { used spirometry to } \\
\text { measure lung capacity } \\
\text { and history. }\end{array}$ & $\begin{array}{l}\text { This study used the } \\
\text { univariate analysis and } \\
\text { bivariate analysis, and } \\
\text { the results showed that } \\
\text { the exposure period was } \\
\text { related to the occurrence } \\
\text { of pulmonary disorders. } \\
\text { However, in this study not } \\
\text { all variables were studied. }\end{array}$ \\
\hline
\end{tabular}

\section{Research Steps}

In the journal of Nafisa, Joko and Setiani (2016) and Alfabet, Suhartono and Nugroho (2017), it was stated that the researchers conducted a study of the relationship of exposure to wood dust to lung function disorders by using purposive sampling to take subjects who met the requirements or criteria that were in line with the research objectives. The study of Nafisa, Joko and Setiani (2016) measured dust levels using Haz Dust EPAM-5000 as preliminary data. Research directed by Putri, Darundiati and Dewanti (2017) and Maratus MS, Suroto and Ekawati (2018) used the total population to determine respondents who took part in the study. Meanwhile, the research directed by Permatasari, Raharjo and Joko (2017) used stratified random sampling to determine respondents by dividing populations into smaller groups so that they were strata based on the same characteristics. Research conducted by Anjani, Raharjo and Budiyono 
(2018) used simple random sampling to determine respondents in a random mode.

Overall, research in the six journals used a cross sectional research design in which research was directed at the same time, and the data collection tools used were questionnaires with an interview method. In general, journals in this literature review research all are related to pulmonary physiology disorders examined by medical respondents using a spirometer. Six journals have used bivariate analysis to obtain out the relationship although not all variables are explained, but there are still some journals that explain the results using univariate analysis.

\section{DISCUSSION}

Wood processing workers can suffer from pulmonary physiology, mainly caused by physical environmental factors found in the workplace environment in the form of wood dust. Pulmonary physiology disorders in workers are also determined by individual characteristics, including age, years of service, length of stay, smoking habits, nutritional status, and use of personal protective equipment (PPE). Moreover, factors that can cause physiological disorders are the use of personal protective equipment (PPE), smoking habits, and length of exposure. Previous work history can also affect the occurrence of pulmonary physiology disorders in workers for example, before working in the wood processing industry workers have already had a history of working in an industry that also produces dust during the production procedure. This condition can also affect the health of workers.

In line with the results of research conducted by Nafisa, Joko and Setiani (2016), it is known that the causes of workers experiencing problems with lung function are work period, use of personal protective equipment (PPE) and dust levels. The work period can affect pulmonary physiology disorders because the longest years of service of wood processing workers in PT. Arumbai Kasembadan Banyumas was more than five years. The longer the working period of a person, the higher the probability of the quantity of exposure received by workers, in this case wood dust. Meanwhile, other factors that can influence the occurrence of pulmonary physiology is the nonobedience of workers in using personal protective equipment (PPE) provided by the workplace. The level of dust at PT. Arumbai Kasembadan Banyumas is known to have exceeded the threshold value (NAV), so if workers work longer and do not comply with the use of personal protective equipment (PPE), it will worsen the condition of the workers' lungs.

The results of the study also have similarities with research of Permatasari, Raharjo and Joko (2017) and Alfabet, Suhartono and Nugroho, (2017) where workers had non-compliant habit in using personal protective equipment (PPE). Problems that often arise related to the use of personal protective equipment (PPE) by workers are the behavior of workers who are less concerned with the use of personal protective equipment (PPE), the absence of supervision in the industrial environment for workers using personal protective equipment (PPE), and incomplete usage of personal protective equipment (PPE) by workers. Problems related to the use of personal protective equipment (PPE) on both studies are the fact that despite having been provided with personal protective equipment, some workers are still not concerned about the use of personal protective equipment (PPE) and some workers also do not fully wear personal protective equipment (PPE) as they feel uncomfortable and stuffy while having a discussion with their coworkers.

In the study of Oviera, Jayanti and Suroto (2016), the high intensity of dust levels that surpassed the threshold value (NAV) caused many workers to experience complaints of pulmonary physiology. The number of workers experiencing health complaints is another component that affects the intensity of dust levels that exceeds the threshold value (NAB); in other words, the habits of workers who often smoke can worsen the occurrence of pulmonary physiology. This result is similar to research of Sumekar and Ediningsih (2016) suggesting that there were several factors that caused pulmonary function disorders such as the intensity of wood dust levels that exceeded the threshold value (NAV), smoking habits of workers, the number of old workers, and less obedience of workers in using personal protective equipment (PPE). In research of Isnaini, Setyoko and Basuki (2015) there were many workers who worked more than 5 years. This made workers get induced by dust exposure with a very long period of time, which was very risky for pulmonary physiology. Similarly, in research of Fujianti, Hasyim and Sunarsih (2015) many workers with a work period that exceeded 5 years did not utilize personal protective equipment (PPE). Besides, some workers worked beyond 8 hours of normal working time, which could worsen the natural occurrence of pulmonary physiology disorders in workers. 
Research conducted by Nafisa, Joko and Setiani (2016); Permatasari, Raharjo and Joko (2017); Putri, Darundiati and Dewanti (2017); Anjani, Raharjo and Budiyono (2018); and Maratus MS, Suroto and Ekawati (2018) have common variables discussed, and it was found that a factor causing pulmonary physiologic disorders is the level of wood dust in the workplace environment. The measurement of wood dust levels carried out by the five journals resulted in numbers that exceeded the threshold value (NAV). The presence of wood dust in the air whose number exceeds the threshold value (NAV) is known to affect the occurrence of pulmonary physiology, which is confirmed by the long exposure to wood dust experienced by workers. Moreover, it does not only takes a short period of time but sometimes also decades for workers to suffer from pulmonary physiology because some workers are exposed to wood dust that is indirectly inhaled every day.

The similarities of the independent variables in the six studies are that they are presented in the univariate analysis table consisting of age, years of service, duration of exposure, use of personal protective equipment (PPE), smoking habits, and dust levels. However, in the bivariate analysis not all variables were analyzed. As in the study of Nafisa, Joko and Setiani (2016) the variables analyzed were length of service, duration of exposure, use of personal protective equipment, and wood dust content. Meanwhile, in research of Putri, Darundiati and Dewanti (2017) and Maratus MS, Suroto and Ekawati (2018) bivariate analysis was held out on dust content variables only. In the study of Alfabet, Suhartono and Nugroho (2017) bivariate analysis was carried out on the variables of length of service, nutritional status, and use of personal protective equipment (PPE), so the variable of wood dust content was not carried out in the bivariate analysis

These ten studies also pose some differences. Some studies measured the total dust content using Haz Dust EPAM-5000 as in research of Nafisa, Joko and Setiani (2016) and (Fujianti, Hasyim and Sunarsih, 2015). Moreover, study by Permatasari, Raharjo and Joko (2017), used secondary data to measure total dust levels. Meanwhile, the study of Putri, Darundiati and Dewanti (2017) and Maratus MS, Suroto and Ekawati (2018) used a High-Volume Air Sampler (HVAS).

\section{CONCLUSION}

Based on the results of research from the six journals, it is known that pulmonary disorders in workers in the wood processing industry are influenced by individual characteristics such as age, years of service, duration of exposure, use of personal protective equipment (PPE), smoking habits, nutritional status, exercise habits and levels wood dust in the work environment. Variables that significantly influence the occurrence of pulmonary physiology are the use of personal protective equipment (PPE) and wood dust.

Levels that exceed the threshold value (NAV). This is known because the six journals the variable levels of wood dust and pulmonary function disorders are presented as the results of bivariate analysis, while the other independent variables such as individual characteristics are only presented in the form of univariate analysis.

\section{ACKNOWLEDGEMENTS}

The researcher would like to express great gratitude the authors of the journals used as the literature review in this study. The researcher also delivers great gratitude for those who have helped in the successful completion of this journal.

\section{REFERENCES}

Alfabet, C. O. G. Y., Suhartono and Nugroho, R. D. (2017) 'Hubungan Beberapa Faktor dengan Fungsi Paru pada Pekerja Wanita di Industri Furniture PT. Ebako Nusantara Semarang Trimester II Tahun 2017', Jurnal Kesehatan Masyarakat (e-Journal), 5(5), pp. 548-560.

Anjani, N. R., Raharjo, M. and Budiyono (2018) 'Hubungan Kadar Debu Terhirup dengan Gangguan Fungsi Paru pada Pekerja Industri Mebel PT Marleny Jepara', Jurnal Kesehatan Masyarakat (e-Journal), 6(6), pp. 259-268.

Anselma, A., Trisnawati, E. and Saleh, I. (2019) 'Hubungan Kadar Debu Pm10 dengan Gangguan Fungsi Paru pada Pekerja Pabrik Cpo (Crude Palm Oil) Di PT.X Provinsi Kalimantan Barat', Jurnal Kesmas (Kesehatan Masyarakat) Khatulistiwa, 6(2), p. 52.

Fujianti, P., Hasyim, H. and Sunarsih, E. (2015) 'Faktor-Faktor Yang Mempengaruhi Timbulnya Keluhan Gangguan Pernapasan pada Pekerja Mebel Jati Berkah Kota Jambi', Jurnal Ilmu Kesehatan Masyarakat, 6(3), pp. 186-194.

Ida, M. R., Doke, S. and Salmun, J. A. R. (2019) 'Faktor - Faktor Yang Berhubungan dengan Gangguan Kesehatan pada Pekerja Mebel Kayu di Kelurahan Oesapa Kecamatan Kelapa Lima 
Kota Kupang', Journal of Public Health, 1(2), pp. $79-88$.

Isnaini, A., Setyoko and Basuki, R. (2015) 'Hubungan Masa Paparan Debu dan Kebiasaan Merokok dengan Fungsi Paru pada Pekerja Mebel Antik Lho di Jepara', Jurnal Kedokteran Muhammadiyah, 2(2), pp. 16-19.

Maratus MS, L., Suroto, S. and Ekawati, E. (2018) 'Hubungan Paparan Debu Kayu Dengan Kapasitas Vital Paru Pekerja Pemotong Kayu di PT.X Mranggen Jawa Tengah', Jurnal Kesehatan Masyarakat (e-Journal), pp. 330-336.

Nafisa, R. S. F., Joko, T. and Setiani, O. (2016) 'Hubungan Paparan Debu Kayu di Lingkungan Kerja Terhadap Gangguan Fungsi Paru pada Pekerja di PT. Arumbai Kasembadan, Banyumas', Jurnal Kesehatan Masyarakat (e-Journal), 4(5), pp. 178-186.

Permatasari, L. O., Raharjo, M. and Joko, T. (2017) 'Hubungan Antara Kadar Debu Total Dan Personal Hygiene dengan Gangguan Fungsi Paru Pada Pekerja Pengolahan Kayu di CV Indo Jati Utama Semarang', Jurnal Kesehatan Masyarakat (e-Journal), 5(5), pp. 717-723.

Purba, A. C. S., Adiputra, L. M. I. S. H. and Muliarta, I. M. (2019) 'Gambaran Fungsi Paru Pengrajin Kayu di Desa Petulu Gianyar, Bali-Indonesia', Intisari Sains Medis, 10(3), pp. 702-706.
Putri, F. Y., Suwondo, A. and Widjasena, B. (2016) 'Hubungan Paparan Debu Kayu dengan Kejadian Dermatitis Kontak Iritan pada Pekerja Mebel PT X Jepara', Jurnal Kesehatan Masyarakat, 4(4), pp. 652-658.

Putri, R. K., Darundiati, Y. H. and Dewanti, N. A. Y. (2017) 'Hubungan Paparan Debu Kayu Terhirup dengan Gangguan Fungsi Paru pada Pekerja di Industri Mebel CV. Citra Jepara Furniture Kabupaten Semarang', Jurnal Kesehatan Masyarakat (e-Journal), 5(5), pp. 833-837.

Rohmah, M., Thohari, I. and Sunarko, B. (2017) 'Pengaruh Kadar Debu Kayu Terhadap Keluhan Pernafasan Pekerja', Gema Kesehatan Lingkungan, 15(1), pp. 6-11.

Sumekar, A. and Ediningsih, E. S. (2016) 'FaktorFaktor Yang Berhubungan Dengan Status Fungsi Paru Pada Pekerja Yang Terpapar Debu di Industri Mebel CV.Annet Sofa Pandowoharjo Sleman Yogyakarta', Jurnal Stikes Wirahusada, 10(1), pp. 688-700.

Suroto, S., Jayanti, S. and Oviera, A. (2016) 'FaktorFaktor Yang Berhubungan Dengan Kapasitas Vital Paru Pada Pekerja Industri Pengolahan Kayu Di PT X Jepara', Jurnal Kesehatan Masyarakat (e-Journal), 4(1), pp. 267-276. 